Gard Ove Sørvik has a PhD in science education. His PhD project, of which this article is a part, was based on data collected through the Budding Science and Literacy project, conducted at the Norwegian Centre for Science Education. He is also a science, mathematics and geography teacher at the Hospital School of Oslo.

Sonja M. Mork is an associate professor at the Norwegian Centre for Science Education, University of Oslo. Mork has a $\mathrm{PhD}$ in science education and a background as a biologist and science teacher. Her research interests are in the field of science literacy and inquiry and she is now leading the Budding Science and Literacy project.

GARD OVE SØRVIK

Department of Teacher Education and School Research, University of Oslo, Norway g.o.sorvik@ils.uio.no

\title{
Scientific literacy as social practice: Implications for reading and writing in science classrooms
}

\section{Abstract}

This article provides an introduction to what it means to adopt a view of literacy as social practice for science education. This view of literacy builds on the idea that reading and writing are best regarded as situated social practices involving text, not as a set of decontextualised and universally applicable skills. First, we draw on sociocultural perspectives on literacy to show how these perspectives inform our understanding of literacy when the context is science. Second, we use related research literature, mainly concerning the role of text in science education, to present a framework for approaching literacy in science classrooms from a sociocultural perspective. Finally, we discuss how a social view of literacy enables us to consider how literacy occurs in contexts relevant to a transcending science subject for scientific literacy.

\section{INTRODUCTION}

Written language has a constitutive and integral role in the social practices that make science possible (Bazerman, 1988; Knorr Cetina, 1999; Latour \& Woolgar, 1986; Norris \& Phillips, 2003). Without text, and the socially meaningful ways of dealing with these texts, science would simply not exist in the way we know it today. In school science, however, texts have traditionally been of little concern to most science teachers and science educators (Hand et al., 2003; Norris \& Phillips, 2003; Pearson, Moje, \& Greenleaf, 2010; Wellington \& Osborne, 2001). This is contrary to the view that students will need to become critical consumers of writing in and about science to actively participate and make informed decisions in a society that is "deeply influenced and shaped by the artefacts, ideas, and values of science" (Osborne, 2007, p. 177). Therefore, the way we approach the notion of literacy in science education contexts is central to both educational practice and research.

The aim of this article is to introduce what a sociocultural perspective on literacy means for science education and the long-term goal of scientific literacy. From this perspective, literacy is regarded as 
situated social practices involving text (e.g. Gee, 2008), rather than the decontextualized notion of "the ability to read and write". First, we will build on sociocultural studies of literacy to show how a social view of literacy informs our understanding of literacy in science education contexts. Second, we will draw on research concerning the role of text in science education and science to consider how literacy can be approached in science classrooms from a sociocultural perspective. While written text, digital and in print, is central to this article, we also include under the concept of text, "any instance of communication in any mode in any combination of modes" (Kress, 2003, p. 48). This is particularly important in science, because science is not done or communicated through language alone, but in combination with other semiotic modes of representations (such as figures, animations, video, images, mathematical formulae, inscriptions, and gestures) (Lemke, 1998).

\section{LITERACY AS SOCIAL PRACTICE}

Norris and Phillips (2003) argue that a "simple view of reading" has pervaded much of the science education literature in general and the literature on scientific literacy in particular. In this view, reading is seen, more or less, as a set of universally applicable skills or competencies (i.e. decoding print and comprehension) to be applied independent of the text or context in which that text is read. Literacy, then, is reduced to a neutral entity that concerns "the ability to read and write", which is often presupposed to be something you acquire through formal schooling. Street (1984) refers to this view as an "autonomous" model of literacy, where literacy in itself - autonomously - will have specific cognitive effects regardless of the context in which these skills are applied. Hence, a simple view of reading ignores readers' diverse backgrounds and the social and cultural conventions that are embedded within a text, even though these dimensions of reading significantly influence readers' understanding (e.g. Norris \& Phillips, 1994; Samuelstuen \& Bråten, 2005).

In contrast to an autonomous model of literacy, sociocultural studies of literacy (often referred to as the "New Literacy Studies") have focused on how reading and writing can only be understood in the contexts of the particular social practices of which they are a part (Barton, 2007; Barton \& Hamilton, 1998; Barton \& Lee, 2013; Gee, 2004, 2008; Heath, 1983; Jewitt, 2008; Street, 1984). This approach to literacy is based on what Street (1984) calls an "ideological" model of literacy, which attempts to understand literacy as a social practice embedded in cultural and ideological contexts. It then becomes clear that literacy involves much more than simply decoding a word or a sentence to make meaning; it involves engaging and participating in "particular ways of thinking about and doing reading and writing in cultural contexts" (Street, 2003, p. 79). In this view, literacy becomes something people do in their everyday life, a social activity, which necessarily also involves people's values, talk, social relationships, attitudes and beliefs regarding text (Barton \& Hamilton, 1998). It follows that literacy is not just one thing; rather, there are multiple literacies just as there are multiple "social practices and conceptions of reading and writing" (Street, 1984, p. 1). From a science education perspective, this means that the literacies of science and school science necessarily co-exist alongside a range of other literacies.

Ultimately, different literacies help us make and communicate meanings to and from other people, whether in or out of schools or other institutions. Take for example a team of glaciologists writing and submitting a research article to the journal The Cryosphere or a group of friends text messaging each other to make plans. These people all adhere to the different conventions and socially recognized ways of using written language within the particular social group or discourse community in which they participate; in other words, they take part in local and situated social practices involving text (Barton \& Hamilton, 1998).

Hence, for science educators, adopting a social view of literacy means to first approach reading and writing (and all the other things we may do with text) as embedded in the social practices that are associated with school science and, by extension, science. It is in these contexts that the texts of school science and science make the most sense (Lemke, 2004). This aligns well with Aikenhead's (1996) 
characterization of school science and science as two interrelated and closely aligned subcultures of Western society. Whilst science has its own aims, practices, norms, conventions, values and languages that are shared by communities of scientists, school science also has its own sets of aims and practices, many of which strive, but often fail, to reflect those of science in an accurate manner. In the context of science, for example, Bazerman (1988, p. 235) noted how "[t]wentieth-century physicists read articles in physics within the activity and structure of twentieth-century physics. Their reading is motivated and shaped by their participation in that communal endeavor". Similarly, when a student reads a text in the context of a science lesson, that reading is framed within a particular situation at a particular time for a particular purpose. Most often, however, those purposes appear to reflect a transmissive pedagogy (Goldman \& Bisanz, 2002; Lyons, 2006), which stresses memorization of well-established scientific knowledge over argumentation and scientific reasoning.

Students also encounter texts with scientific information in a number of ways in their daily lives as well as within the classroom. It is in this regard important to acknowledge that certain socially powerful institutions, such as school or the workplace, exert a greater influence on how literacy is perceived by the general public than other domains in everyday life (Barton, 2007). When approaching literacy from the perspective of school science, it thus becomes purposeful to consider which literacy practices are usually formal, dominant and valued in the context of school science, and which are informal, everyday and of personal choice (Barton \& Hamilton, 1998; Gee, 2004; Street, 1993). In a school science context, or in any educational context, school-related or academic literacy practices (e.g. reading a science textbook or copying notes from the whiteboard) tend to be supported, privileged and regulated by others (i.e. the teacher), whereas everyday and student-initiated literacy practices are usually not (Alvermann, 2002). Indeed, as Alvermann (2002, p. 190) argues, "[ $t$ ]his privileging elevates the importance and value of academic reading but tells teachers little about their students' everyday uses of language and literacy". Since certain texts and certain ways of using text in the science classroom will always be foregrounded and more dominant than others, the role of text in school science will inevitably influence how students perceive literacy in science and in their daily lives. Moreover, it becomes evident that the ways in which language and literacy are framed in school science are packed with ideology and highly significant to consider for all science educators (Knain, 2001; Wickman, Liberg, \& Östman, 2012).

Taking a sociocultural perspective on literacy also has implications for how we approach the overarching notion of scientific literacy - a term that is often used, albeit with a wide variety of meanings, to refer to "what we expect students to know and be able to do as a result of their science learning experiences" (Sadler \& Zeidler, 2009, p. 910). Although literacy is somewhat inherent in the term, it has not been a specific focus in the literature on scientific literacy until recent years. Most notably, Norris and Phillips (2003) - in a highly influential article - theoretically positioned literacy, in its literal meaning, as the fundamental sense of scientific literacy (being able to read and write science text) to the derived sense of scientific literacy (being learned, knowledgeable and educated in science). A social view of literacy further broadens the ways in which we consider literacy in science by paying specific attention to the contexts in which scientific information is used and produced. This is clearly articulated by Knain (2015), who argues that the discourse of school science must draw its relevance from participation in various secondary discourses in society.

A move towards recognizing the situated nature of literacy is also paralleled in Roberts' (2007) two competing visions of scientific literacy: Vision I and Vision II. Whereas Vision I is seen as looking "inward" at the products and processes of science, from the perspective of the professional scientist, Vision II looks "outward" at situations that students are likely to encounter in daily life where science plays a role, in combination with other considerations (e.g. values, aesthetics, politics). In Vision I, there is thus a presumption that science, in itself, is valuable and transferable to situations later in life (reminiscent of the autonomous model of literacy). In contrast, Vision II questions whether scientific knowledge is directly useful in everyday contexts beyond the context of science (e.g. Layton, 
Jenkins, Macgill, \& Davey, 1993). From our perspective on literacy, the contexts that shape and are shaped by literacy cannot be disregarded. Thus, it could be said that a social view of literacy presupposes a context-sensitive approach to scientific literacy. Similarly, Wickman, et al. (2012) start from a Vision II approach to make a strong argument for what they call a transcending science subject. They argue that school science needs to transcend not only the context of science, but also the idiosyncratic backgrounds and experiences of students to prepare them for making personal decisions on matters involving science in their daily lives. In a transcending science subject, a social view of literacy can provide a suitable framework for considering how various texts with scientific information function and are used across these contexts: in the daily lives of students and citizens, in science classrooms, and in communities of practising scientists.

\section{A FRAMEWORK FOR APPROACHING LITERACY IN SCHOOL SCIENCE}

In what follows, we draw on research related to the role of text in science education to outline what a social view of literacy implies for teachers' educational practice. The framework is structured around four key elements of literacy in science classrooms; namely that:

1. Science texts are written for particular purposes and audiences

2. School science literacies build on students' informal literacy practices

3. Science reading and writing activities in school differ in their "authenticity"

4. Students benefit from explicit instruction

These elements are meant to support science teachers and science educators in developing reading and writing activities in school that are meaningful and relevant to their students and their vision of scientific literacy. For each of the four elements, we also provide brief examples of how this can be addressed in the classroom.

\section{Science texts are written for particular purposes and audiences}

In this framework, science texts act as a natural starting point for considering the wider social practices and contexts in which these texts are used, produced, and accordingly gain meaning. Goldman and Bisanz (2002) suggest that there are three main roles for science communication through the medium of text in society today: 1) communication among scientists; 2) popularization of scientific information; and, 3) the provision of formal education that prepares individuals for future careers in science or as scientifically literate citizens. These three roles, and the audiences for whom these texts are written, will here be used to examine a broad range of scientific texts.

Science In science, professional scientists read and write in their day-to-day practices for purposes that reflect the culture, values and beliefs of the scientific community (see e.g. Latour \& Woolgar, 1986; Knorr Cetina, 1999 for detailed accounts of scientific practice). Even the laboratory appears as "a system of literary inscription" (Latour \& Woolgar, 1986, p. 52), where scribbled notes, images, graphs, numbers and texts from inscription devices continually frame the material practices scientists engage in. Their research is formalized through research reports, most notably the experimental journal article, which is written within the traditions of their scientific discipline and subjected to the scrutiny of their peers (Bazerman, 1988). These, and other central texts (e.g. conference presentations, conceptual overviews, and procedural texts) normally contain specialist language and multiple representations that provide scientists with a means to produce, organize, and communicate knowledge about the natural world (Fang, 2005; Halliday \& Martin, 1993; Lemke, 1998). In this way, it can be said that "scientific knowledge relies upon the cumulative discourse made possible by text" (Norris \& Phillips, 2003, p. 233). As scientists find new ways of understanding and communicating knowledge, the specialized texts of science also develop to fit the needs of the scientific community (Halliday \& Martin, 1993; Mork \& Erlien, 2010). Over the past two decades, however, the most influential change has arguably been the shift from print to online media in combination with an increasing amount of 
Open Access journals, making scientific research literature ever more available to persons outside the scientific community (Willinsky, 2006).

Popular science Scientific information is also popularized to inform the general public, by journalists or the scientists themselves, and incorporated into popular culture through media such as television, literature, blogs, and advertisements (Norris \& Phillips, 1994; Weingart, Muhl, \& Pansegrau, 2003). When science is reported in the news, it is often transformed from primary literature to fit with conventions for reporting the news. This might involve using controversial statements, prioritizing results over the robustness of the research, or reporting on frontier science that may still be disputed. Thus, readers are often required to evaluate the scientific arguments, question the biases, and judge the trustworthiness of the knowledge claims presented, on insufficient information (Zimmerman, Bisanz, Bisanz, Klein, \& Klein, 2001). Controversial socio-scientific issues (SSI), in particular, are typically reported in the news and likely to be issues that students are confronted with in their daily lives (Kolstø, 2001; Mork, 2005). In addition, television programmes with science elements (such as CSI or Grey's Anatomy) appear to be important sources of inspiration for pursuing careers in science (Henriksen, Jensen, \& Sjaastad, 2014), indicating that these types of popular science texts can have both value and relevance in the classroom.

Science education Whereas science communication among scientists and popular reports of science tend to focus on controversial or ground-breaking "science-in-the-making", texts designed for formal education in science deal mostly with consensual and established scientific knowledge, or "ready-made-science" (Latour, 1987). This is perhaps best exemplified by the textbook, which is - and has long been - the dominant genre in science classrooms (Nelson, 2006). In a literature review on science textbook use, Nelson (2006) summarizes how textbooks often collect statements of facts about the natural world, making them timesaving for teachers, but also a strong influence on their instruction. As a consequence, many science educators have been hesitant towards reading and writing in school science, especially those related to the inquiry tradition of science education (Pearson et al., 2010). Teachers' main concern is often that their students might defer to the authority of the text, rather than investigating and generating answers based on their own first-hand experiences (Palincsar \& Magnusson, 1997). However, as emphasized by Nelson (2006), what matters most is how a textbook is used, not necessarily the structure and content of the textbook itself. In later years, science educators interested in the authentic ways in which scientists read, write, and talk science, have therefore developed a range of novel text genres and activities specifically designed to support students at different stages in their inquiry processes (Pearson et al., 2010).

From a sociocultural perspective on literacy, science education represents a context that can support students in gaining access to social practices where scientific communication plays a role. Hence, literacy in a transcending science subject (cf. Wickman et al., 2012) must include a wide range of texts and practices that are relevant to contexts beyond the classroom, such as professional science, SSI, and daily life. In practice, Munkebye and Munkebye (2013) provide one example of how texts written for different purposes can be used in the classroom. They describe how a primary school science teacher used a newspaper article, along with a textbook and other texts to discuss specific characteristics of informational texts with the students and identify different types of scientific texts. The students then relied on these encounters to make their own informational texts with headlines, figures, and captions.

\section{School science literacies builds on students' informal literacy practices}

While literacy is often associated with formal schooling and academic ways of reading and writing, a social view of literacy implies that literacy in school is just part of the picture (Barton, 2007). School is just one context in which literacy is embedded and used by those connected to school through their various roles and power relations (e.g. teachers, students, principals, janitors). What is specific about school, however, is that schools have "distinct ways of doing things, and particularly a set of practices 
around language use and around literacy" (Barton, 2007, p. 176), which contribute to construct and shape students' literacy practices at school (Jewitt, 2008). This relates to what we have described as a distinction between formal or dominant literacies and literacies that are informal, of individual choice, and rooted in everyday life (cf. Barton \& Hamilton, 1998). For many students, the differences between how they use literacy at home and the practices valued in the science classroom may not be easily reconcilable, and sometimes even in conflict (Aikenhead, 1996; Heath, 1983).

The relationship between home and school literacies was perhaps most clearly illustrated in Heath's (1983) seminal ethnographic study of how literacy was embedded in the contexts of three rural North Carolina communities in the United States. Heath recorded how people in the three communities used reading and writing in their everyday lives, and identified how each community had different "ways with words". However, it was only in one community - the mainstream middle-class residents of the town - where children's home literacy practices were congruent with the school-based literacy practices. In the other communities, text served distinctly different purposes than those at school, which caused these students to be unsuccessful at school. Heath's study reminds us not only of the local and situated nature of literacy, but also of the need for science educators to familiarize ourselves with students' backgrounds and experiences with literacy outside school.

In the science classroom, students inevitably bring their own experiences with literacy and science to bear when negotiating scientific ways of using written language. It then becomes a question of whose literacies are valued, welcomed and supported in the classroom. In a study of the home and school resources that frame students' literacy learning in science, Moje and colleagues (2004) showed how students used relevant representations from popular culture, such as television and news media, to frame their understandings of related science concepts outside the school context. In school, on the other hand, students were reluctant to contribute and rely on these resources. Similarly, Olander (2013) demonstrated how correct explanations were privileged by the teacher over everyday coping and self-explanation in a 9th grade science class. However, the students themselves made intertextual links to their own lives and experiences, moving the classroom discourse more towards a Vision II perspective of scientific literacy (Olander, 2013). Studies like these clearly emphasize the importance of actively constructing spaces in school where students' everyday experiences and ways with words are drawn upon and connected to literacy practices that are valued in science education.

Sørvik, Blikstad-Balas and Ødegaard (2015) documented evidence of multiple literacies, which attended to markedly different purposes, in the six primary school science classrooms that were studied . On the one hand, students engaged in literacy practices that were typically "schooled", in the traditional sense, such as reading a definition from a concept wall or writing to document a task. On the other hand, students also incorporated informal elements from their everyday literacy practices as valuable resources in the dialogic process of inquiry. This was perhaps most prominent in a literacy event that took place around Google Images in a third-grade classroom. The students had watched a video of a humming bird to observe its characteristics, but did not agree on whether it was possible to observe that the humming bird had two or four limbs ("Look, it has no legs!" one student firmly insisted). One of the other students in the class then repeatedly asked if they could go online to find an image of a humming bird instead of watching the video over again ("Can't we just find a picture. It's so much easier"). Eventually, the teacher agreed and the class jointly used Google Images to find evidence of humming birds having four limbs. In the following lessons, searching for images online became a valued practice in this classroom and was used to collect data on the characteristics of different animals. What was especially interesting about this event was that it concerned a practice suggested by a student, which was then picked up by the teacher and reframed for a school scientific purpose. Across the six classrooms in the study, several other hybrid literacy practices emerged, as students incorporated their own experiences and textual resources into school science literacy practices (e.g. using science fiction texts as prior knowledge). In this regard, it is interesting to note that scientists - as so clearly shown by the work of Latour and others (e.g. Latour \& Woolgar, 1986) - also 
rely on text and talk in a number of informal ways during the process of scientific inquiry, not solely the formalized accounts that are eventually published in peer-reviewed journals and often bear little resemblance to the actual process.

Still, as Jewitt (2008) emphasizes, the ways in which everyday or informal literacies are incorporated into school science is nevertheless a matter of power: "it is about what is allowed to count, to whom, and for what purpose” (p. 253). This does not imply that everyday ways of reading (and writing and talking) should be prioritized over scientific language. Rather, building on students' informal literacy practices involves acknowledging that there are multiple literacies and discourses at work in the classroom, sometimes even co-existing, which relate to different purposes, different social contexts, and different backgrounds and experiences.

\section{Science reading and writing activities in school differ in their "authenticity"}

The third element in the framework concerns the out-of-school applications and contexts for engaging with literacy in the science classroom. While we do not use a term like authenticity without reservation - as we believe that any situation involving text is in some sense authentic to the participant (i.e. the student) - we will use the term here to consider how literacy in school science relates to relevant contexts and social practices beyond the classroom (Gee, 2001). Likewise, Purcell-Gates, Duke, and Martineau (2007, p. 14) use the notion of "authenticity" to differentiate between literacies that are confined to the context of school science and literacies that transcend "real-world" contexts, like professional science, society, or home.

In line with related work on situated learning and cognition in science education (Sadler, 2009), a social view of literacy implies that reading and writing is something people do for particular purposes in particular sociocultural contexts. Thus, learning to read (or write) a certain text in a certain way requires "having access to, and ample experience in, social settings where texts of that type are read in those ways" (Gee, 2008, p. 48). The consequence for school science is that science education must be positioned as contexts for exploring actual uses of scientific information outside the confines of the classroom, most notably the contexts of science and society. A prominent example of how this can be achieved in the classroom is the Norwegian student journal $S P I S S^{1}$, which publishes peer-reviewed articles of and for Technology and theory of research ${ }^{2}$ students in upper secondary school. The articles are based on students' own research projects, and reviewed by students from other schools. In this way, SPISS serves as an authentic arena - closely aligned with the context of professional science - to read and evaluate other students' work, as well as receive feedback on their own work.

There is, however, an increasing body of research indicating that students often experience school science as the transmission of scientific facts from expert sources, such as the teacher or the textbook (Lyons, 2006). In this mode of science teaching, reading and writing is mostly reduced to distinctly "schooled" literacy practices, such as copying information from the blackboard or the textbook, memorizing information before a test, or answering textbook questions (Danielsson, 2010; Driscoll, Moallem, Dick, \& Kirby, 1994; Lindahl, 2003; Osborne \& Collins, 2001). Rather than being connected to meaningful contexts in which scientific information is actually used, reading and writing in school science becomes embedded in a school science culture that emphasizes the memorization of "important" information (Goldman \& Bisanz, 2002). In contrast, when students engage in authentic literacy activities in school science, research has shown that these activities are also impressively related to students' increased comprehension and production of informational and procedural science texts (Purcell-Gates et al., 2007).

The notion of authentic literacy activities in school becomes clearer when we look to other contexts in which scientific information is read or written on a daily basis. For example, while scientists often

\footnotetext{
${ }^{1}$ www.naturfagsenteret.no/spiss

${ }^{2}$ Technology and theory of research is a science specialization subject for upper secondary students in Norway.
} 
write to inform or persuade the reader about a particular argument or result (Yore, Hand, \& Prain, 2002), these are dimensions of science writing (the purpose and audience of a text) that are rarely talked about in the classroom (Af Geijerstam, 2006). Instead, when literacy is actively used in the service of scientific inquiry, students read and write to investigate phenomena, discuss interpretations and arguments based on data, and communicate these ideas to their peers or other audiences (Pearson et al., 2010; Sørvik et al., 2015; Ødegaard, Haug, Mork, \& Sørvik, 2014). Similarly, when engaging in SSI, it is necessary to evaluate information across different media not only from a scientific perspective, but also in interaction with the specific social, political, economic, and value positions that affect the situation (Kolstø, 2001). In the classroom, this means that students can authentically communicate across several meaningful contexts if they are dealing with complex SSI (i.e. from various social and economic perspectives or from a purely scientific perspective) (Knain \& Kolstø, 2011; Mork, 2005). For instance, they can compare how climate change research is presented in newspapers and research reports, and discuss these texts from the perspectives of a journalist, scientist, or consumer.

Nevertheless, it is important to emphasize that literacy practices often considered as traditional or "schooled" are also a part of the literacies of school science, but they cannot be the only form of literacy that students encounter in the science classroom if the situated nature of literacy is to be taken into account. Sørvik et al. (2015) showed how many of the daily routines and scaffolding practices in primary school science classrooms were dependent on text. These were distinctly schooled practices, but they were also integrated with the students' inquiry activities to provide structure and guidance. Knain and Kolstø (2011) describe similar literacy practices for upper secondary students engaging with inquiry and socio-scientific issues in terms of specific "support structures". They identify, for example, the use of wikis as a planning tool, learning goals, evaluation criteria, suggested information sources, short lectures by the teacher, and writing templates. Purcell-Gates et al. (2007) also claim that "schooled" ways of using text and "authentic" reading and writing activities in school are not mutually exclusive. Rather, depending on teachers' choice of text and purposes for using these texts, school-only activities can also be experienced as meaningful for students in a school science context.

\section{Students benefit from explicit instruction}

The last element of the framework concerns explicit instruction, which has been particularly central in work on reading and writing strategies, and reading comprehension (Kolstø, 2009; Mork \& Erlien, 2010; Wellington \& Osborne, 2001). Adopting a social view of literacy involves just as much how we talk about texts as how we read and write those texts. Information is stored in scientific texts and genres as they incorporate the conventions, norms and values of science, and separate them from other types of texts. However, these genres are largely unfamiliar to students (Wellington \& Osborne, 2001), making it especially important to provide structures that support them in gradually using the communication forms and language of science, as well as developing an understanding of how these language conventions are related to the social practices and ways of thinking in science.

It has long been debated how new language forms are best learned, particularly those that are not acquired in everyday discourse. Those asserting that language is best learned by explicit instruction seem to be at one end of a continuum, while those claiming that language can only be learnt through participating in situated use of particular language forms are at the other. Purcell-Gates et al. (2007) emphasize that most researchers (including the authors) and teachers hold a middle position that includes a combination of embedded experiences and explicit instruction.

Several studies have shown that explicit instruction on reading strategies and text structure can improve comprehension and composition of such structures (e.g. Anthony, Tippett, \& Yore, 2010; Guthrie et al., 2004). Anthony et al. (2010) showed that students who had worked on the brochure genre and made their own brochures were better able to read and identify information in unknown brochures as compared to the control group. In contrast, in a longitudinal study of literacy activities and explicit teaching in grades two and three, Purcell-Gates et al. (2007) reported that students' abi- 
lities to comprehend and write science informational and procedural texts were not enhanced by explicit instruction of relevant linguistic features. The authors suggested several possible explanations for the results; for example, the students' age, type of genre, methodological issues, and that explicit instruction of genre should be combined with explicit teaching of reading and writing strategies to be effective. Purcell-Gates et al. (2007) concluded that explicit teaching of the features of procedural texts must be in the context of authentic use of that text type for greater growth in the ability to produce it.

Mork (2012) studied examples of how lack of modelling and explicit instruction in a specific lesson influenced third-graders writing a log to summarize their investigation of making glue with different ingredients. The activity started out with a short whole-class summary at the smart board, before the students were told to write a log. The excerpt below illustrates the teacher's initial instructions and subsequent instructions given during this lesson as the students continually asked about what they should write:

Table 1. Teacher instructions during a scientific log writing session in third-grade (Mork, 2012).

\begin{tabular}{|lll|}
\hline Time & Speaker & Utterance \\
\hline $5 \mathrm{~min}$. & Teacher: & $\begin{array}{l}\text { We are going to write a log about what we did yesterday and today. You } \\
\text { should write in your own words. The sentences on the smart board are only for } \\
\text { assistance. }\end{array}$ \\
$8 \mathrm{~min}$. & A log is that you write about the work we did. \\
$20 \mathrm{~min}$. & Teacher: & A log is to write about what we have done. A kind of report. \\
Don't write everything you read about in the book yesterday. You should write \\
more about what you did when you did the research. Write about the experi- \\
ment, what you did, that is the part that is exciting to read about afterwards. \\
You can use concepts from the concept wall. \\
$32 \mathrm{~min}$.
\end{tabular}

The excerpt in table 1 shows that the initial instructions from the teacher were vague, and that she needed to specify the task five times during a 45-minute lesson. The class, who were normally rather quiet, became restless and continually asked about what they should write. Several students started copying sentences from the science trade book they had read the day before. As we see from the excerpt, even the teacher became insecure about the text she wanted her students to write; she started mixing features from several genres (logs and reports). When a sample of students were interviewed after the lesson and asked if they had used their imagination during the lessons, several students in this group said that they had used their imagination when writing the log-indicating that they had not understood the purpose of scientific log writing (Sørvik et al., 2015). In this case, explicit instruction about the purposes and conventions for writing a scientific log could clearly have supported the students in writing this particular text.

\section{DISCUSSION: A SOCIAL VIEW OF LITERACY}

In this article, we have argued that a social view of literacy provides science education with the theoretical perspectives to examine the role of literacy in a transcending science subject (cf. Wickman et al., 2012). Central to this view of literacy is the situated nature of reading and writing, which enables us to consider how literacy is a part of contexts that influence science education and are relevant to the long-term goal of scientific literacy. The most notable of these contexts, we argue, are students' daily lives as citizens in a democratic society, school science, and professional science. Literacy, then, cannot be viewed as an additional element to science education, but becomes a constitutive practice of school science that cannot be ignored if students are to truly become scientifically literate (Gee, 2008; Osborne, 2002). Relying on the idea that literacy is best understood as something people do 
with text in their everyday lives-not a set of skills that you either have or do not have-we have then presented a four-part framework that illustrates what a social view of literacy implies for science educators in practice.

The logical entry point of the framework concerns the range of texts through which science is represented, communicated, and used by scientists, the general public, and students. The potential use of these types of text in the classroom, we claim, should build on students' own experiences and informal literacy practices, relate to authentic contexts and issues, and be combined with explicit instruction about the specialized language conventions of science.

For science education, a social view of literacy also implies that the literacy practices associated with school science are always in a state of constant change. They are at once shaped by social, historical, cultural and political factors, such as the local traditions of science teaching, curriculum reforms, the current foci of the science education community, and the changing nature of learners' lived lives in the digital information age-some of which change more quickly than others. In this regard, it is worth elaborating on how different views of scientific literacy will translate into differently valued literacy practices in local science classrooms. As Feinstein (2011, p. 172) clearly emphasizes:

Educators do not promote the development of literacy practices with equal energy. Instead, we encourage particular practices that support socially valued ends. Although it may be true that literacy practices contribute to any vision of useful science education, different descriptions of science literacy imply different literacy practices.

From our perspective on literacy, this means that there will always be multiple school science literacies-the sociocultural ways in which literacy occurs in science learning environments-related to different conceptualizations of science education and scientific literacy. Accordingly, adopting a social view of literacy does not represent a set of pre-determined literacy practices to promote in science classrooms, but it presents us with a means to reflect on how and why scientific information is used in various societal contexts that are important to our vision of scientific literacy. Unfortunately, when literacy is regarded as a social practice, it also becomes apparent that many of the prevalent literacy practices in science classrooms rarely provide students with opportunities to transcend the school setting. This seems especially worrying if science education is to prepare students for participating in complex environmental SSI (Knain, 2015) and when the online environments of new media and Web 2.0 are continually changing people's literacy practices and use of available information outside school (Barton \& Lee, 2013).

In this article, it should also be noted that professional science has largely been presented as a single, unified entity, which, of course, it is not. This is particularly evident in the work of Karin Knorr Cetina (1999) on two different laboratories (one in high-energy physics and one in molecular biology), where she shows how the sciences exhibit distinctly different practices and "machineries" for constructing and validating knowledge. Furthermore, the work of Tenopir and King (Tenopir \& King, 2004; Tenopir, King, Edwards, \& Wu, 2009) on scientists' journal article readings efficiently demonstrates the multiplicity of literacy in the sciences. Whereas astronomers and chemists were estimated to average 228 readings and 276 readings per year per faculty member, engineers (applied scientists) were estimated to average 98 readings per year per faculty member. Engineers did, on the other hand, spend a lot of time reading other types of scientific output in addition to scholarly journal articles, such as e-mails, internal and external reports, books, trade journals, and patents (Tenopir \& King, 2004).

Finally, for researchers interested in exploring literacy across contexts, a social view of literacy implies that literacy must be investigated in the context in which it occurs (Blikstad-Balas \& Sørvik, 2015). Along this line of research, studies that investigate young people's literacy practices and activities involving science beyond the classroom would not only greatly add to our understanding of how new 
and digital literacies influence students' relationships with socio-scientific issues and science texts in their daily lives, but also to how this relates to the social practices of school science. This, and similar research into various science literacies across different social contexts (in and out of school), might hopefully advance science educators in having learners read and write meaningful texts in contexts that are meaningful and relevant to their science education.

\section{REFERENCES}

Af Geijerstam, Åsa. (2006). Att skriva i naturorienterande ämnen i skolan [Writing in Natural Sciences in School] Studia Linguistica Upsalensia 3. Uppsala: Acta Universitatis Upsaliensis.

Aikenhead, Glen S. (1996). Science Education: Border Crossing into the Subculture of Science. Studies in Science Education, 27(1), 1-52.

Alvermann, Donna E. (2002). Effective literacy instruction for adolescents. Journal of Literacy Research, 34(2), 189-208.

Anthony, Robert J, Tippett, Christine D, \& Yore, Larry D. (2010). Pacific CRYSTAL Project: Explicit Literacy Instruction Embedded in Middle School Science Classrooms. Research in Science Education, 4O(1), 45-64.

Barton, David. (2007). Literacy: an introduction to the ecology of written language. Malden, Mass.: Blackwell Publ.

Barton, David, \& Hamilton, Mary. (1998). Local literacies: Reading and writing in one community. London: Routledge.

Barton, David, \& Lee, Carmen. (2013). Language Online: Investigating Digital Texts and Practices. London: Routledge.

Bazerman, Charles. (1988). Shaping written knowledge: the genre and activity of the experimental article in science. Madison, Wis.: University of Wisconsin Press.

Blikstad-Balas, Marte, \& Sørvik, Gard Ove. (2015). Researching literacy in context: using video analysis to explore school literacies. Literacy 49(3), 140-148.

Danielsson, Kristina. (2010). Learning Chemistry. Text Use and Text Talk in a Finland-Swedish Chemistry Classroom. IARTEM e-Journal, 3(2), 1-28.

Driscoll, Marcy P, Moallem, Mahnaz, Dick, Walter, \& Kirby, Elizabeth. (1994). How does the textbook contribute to learning in a middle school science class? Contemporary educational psychology, 19(1), 79-100.

Fang, Zhihui. (2005). Scientific literacy: A systemic functional linguistics perspective. Science Education, 89(2), 335-347.

Feinstein, Noah. (2011). Salvaging science literacy. Science Education, 95(1), 168-185.

Gee, James Paul. (2001). Reading as situated language: A sociocognitive perspective. Journal of Adolescent \& Adult Literacy, 44(8), 714-725.

Gee, James Paul. (2004). Situated language and learning: A critique of traditional schooling. London: Routledge.

Gee, James Paul. (2008). Social linguistics and literacies: Ideology in discourses (3. ed.). London: Routledge.

Goldman, Susan R, \& Bisanz, Gay L. (2002). Toward a functional analysis of scientific genres: Implications for understanding and learning processes. In J. Otero, J. A. León \& A. C. Graesser (Eds.), The psychology of science text comprehension (pp. 19-50). Mahwah, NJ: Lawrence Erlbaum Associates, Inc.

Guthrie, John T, Wigfield, Allan, Barbosa, Pedro, Perencevich, Kathleen C, Taboada, Ana, Davis, Marcia H, . . Tonks, Stephen. (2004). Increasing Reading Comprehension and Engagement Through Concept-Oriented Reading Instruction. Journal of Educational Psychology, 96(3), 403-423.

Halliday, Michael A. K, \& Martin, James. R. (1993). Writing science: Literacy and discursive power. London: The Falmer Press.

Hand, Brian M., Alvermann, Donna E., Gee, James, Guzzetti, Barbara J., Norris, Stephen P., Phillips, Linda M., ... Yore, Larry D. (2003). Message from the "Island group": What is literacy in science literacy? Journal of Research in Science Teaching, 4O(7), 607-615. 
Heath, Shirley Brice. (1983). Ways with words: Language, life and work in communities and classrooms. Cambridge: Cambridge university Press.

Henriksen, Ellen Karoline, Jensen, Fredrik, \& Sjaastad, Jørgen. (2014). The Role of Out-of-School Experiences and Targeted Recruitment Efforts in Norwegian Science and Technology Students' Educational Choice. International Journal of Science Education, Part B, 1-20.

Jewitt, Carey. (2008). Multimodality and Literacy in School Classrooms. Review of Research in Education, 32(1), 241-267.

Knain, Erik. (2001). Ideologies in school science textbooks. International Journal of Science Education, 23(3), 319-329.

Knain, Erik. (2015). Scientific Literacy for Participation: A Systemic Functional Approach to Analysis of School Science Discourses. Rotterdam: Sense Publishers.

Knain, Erik, \& Kolstø, Stein Dankert (Eds.). (2011). Elever som forskere i naturfag [Students as scientists]. Oslo: Universitetsforlaget.

Knorr Cetina, Karin. (1999). Epistemic cultures: How the sciences make knowledge. Cambridge, Mass.: Harvard University Press.

Kolstø, Stein Dankert. (2001). Scientific literacy for citizenship: Tools for dealing with the science dimension of controversial socioscientific issues. Science Education, 85(3), 291-310.

Kolstø, Stein Dankert. (2009). Vektlegging av lesing i naturfaget. Del 1: Vil den nye norske læreplanen i naturfag øke elevenes lesekompetanse? [Emphasizing reading in science. Part 1: Will the new Norwegian curriculum reform contribute to students' reading competences?] Nordic Studies in Science Education, 5(1), 61-74.

Kress, Gunther. (2003). Literacy in the New Media Age. London: Routledge.

Latour, Bruno. (1987). Science in action: How to follow scientists and engineers through society. Cambridge, MA: Harvard University Press.

Latour, Bruno, \& Woolgar, Steve. (1986). Laboratory life: The social construction of scientific facts (2 ed.). Princeton, New Jersey: Princeton University Press.

Layton, David, Jenkins, Edgar, Macgill, Sally, \& Davey, Angela. (1993). Inarticulate science? Perspectives on the public understanding of science and some implications for science education. Driffield, U.K.: Studies in Education.

Lemke, Jay L. (1998). Multiplying meaning: Visual and verbal semiotics in scientific text. In J. R. Martin \& R. Veel (Eds.), Reading science (pp. 87-113). London: Routledge.

Lemke, Jay L. (2004). The literacies of science. In E. W. Saul (Ed.), Crossing borders in literacy and science instruction: Perspectives on theory and practice (pp. 33-47). Newark, DE: International Reading Association.

Lindahl, Britt. (2003). Lust att lära naturvetenskap och teknik?: en longitudinell studie om vägen till gymnasiet [Pupils' responses to school science and technology? A longitudinal study of pathways to upper secondary school]. (Dissertation 196), Acta Universitatis Gothoburgensis, Göteborg.

Lyons, Terry. (2006). Different countries, same science classes: Students' experiences of school science in their own words. International Journal of Science Education, 28(6), 591-613.

Moje, Elizabeth Birr, Ciechanowski, Kathryn McIntosh, Kramer, Katherine, Ellis, Lindsay, Carrillo, Rosario, \& Collazo, Tehani. (2004). Working toward third space in content area literacy: An examination of everyday funds of knowledge and discourse. Reading Research Quarterly, 39(1), 38-70.

Mork, Sonja M. (2005). Argumentation in science lessons: Focusing on the teacher's role. Nordic Studies in Science Education, 1(1), 17-30.

Mork, Sonja M. (2012). Literacy in science. Paper presented at the Seminar on languages and schooling in all subjects, Council of Europe, Strasbourg.

Mork, Sonja M, \& Erlien, Wenche. (2010). Språk og digitale verktøy i naturfag [Language and digital tools in science]. Oslo: Universitetsforlaget. 
Munkebye, Astrid, \& Munkebye, Eli. (2013). Å lese på småskoletrinnet - med fokus på naturfaglige sjangere og språk. [Reading in primary school - focusing on scientific genres and language.] Naturfag, 2013(1), 50-54.

Nelson, Johan. (2006). Hur används läroboken av lärare och elever? [How is the textbook used by teachers and students?]. Nordic Studies in Science Education, 2(2), 16-27.

Norris, Stephen P., \& Phillips, Linda M. (1994). Interpreting pragmatic meaning when reading popular reports of science. Journal of Research in Science Teaching, 31(9), 947-967.

Norris, Stephen P., \& Phillips, Linda M. (2003). How literacy in its fundamental sense is central to scientific literacy. Science Education, 87(2), 224-240.

Olander, Clas. (2013). Why am I learning evolution? Pointers towards enacted scientific literacy. Journal of Biological Education, 47(3), 175-181.

Osborne, Jonathan. (2002). Science Without Literacy: A ship without a sail? Cambridge Journal of Education, 32(2), 203-218.

Osborne, Jonathan. (2007). Science education for the twenty first century. Eurasia Journal of Mathematics, Science \& Technology Education, 3(3), 173-184.

Osborne, Jonathan, \& Collins, Sue. (2001). Pupils' views of the role and value of the science curriculum: a focus-group study International Journal of Science Education, 23(5), 441-467.

Palincsar, Annemarie Sullivan, \& Magnusson, Shirley J. (1997). The interaction of first and second hand investigations in guided inquiry science teaching. Paper presented at the annual conference of the National Reading Conference, Austin, TX.

Pearson, P. David, Moje, Elizabeth, \& Greenleaf, Cynthia. (2010). Literacy and Science: Each in the Service of the Other. Science, 328(5977), 459-463.

Purcell-Gates, Victoria, Duke, Nell K., \& Martineau, Joseph A. (2007). Learning to read and write genre-specific text: Roles of authentic experience and explicit teaching. Reading Research Quarterly, 42(1), 8-45.

Roberts, Douglas A. (2007). Scientific literacy/science literacy. In S. K. Abell \& N. G. Lederman (Eds.), Handbook of research on science education (pp. 729-780). Mahwah, New Jersey: Lawrence Erlbaum Associates.

Sadler, Troy D. (2009). Situated learning in science education: socio-scientific issues as contexts for practice. Studies in Science Education, 45(1), 1-42.

Sadler, Troy D., \& Zeidler, Dana L. (2009). Scientific literacy, PISA, and socioscientific discourse: Assessment for progressive aims of science education. Journal of Research in Science Teaching, 46(8), 909-921.

Samuelstuen, Marit S., \& Bråten, Ivar. (2005). Decoding, knowledge, and strategies in comprehension of expository text. Scandinavian Journal of Psychology, 46(2), 107-117.

Street, Brian V. (1984). Literacy in theory and practice (Vol. 9). Cambridge: Cambridge University Press.

Street, Brian V. (1993). The new literacy studies. Journal of Research in Reading, 16(2), 81-97.

Street, Brian V. (2003). What's "new" in New Literacy Studies? Critical approaches to literacy in theory and practice. Current issues in comparative education, 5(2), 77-91.

Sørvik, Gard Ove, Blikstad-Balas, Marte, \& Ødegaard, Marianne. (2015). "Do Books Like These Have Authors?” New Roles for Text and New Demands on Students in Integrated Science-Literacy Instruction. Science Education, 99(1), 39-69.

Tenopir, Carol, \& King, Donald W. (2004). Communication patterns of engineers. Piscataway, NJ.: IEEE Press.

Tenopir, Carol, King, Donald W, Edwards, Sheri, \& Wu, Lei. (2009). Electronic journals and changes in scholarly article seeking and reading patterns. Aslib Proceedings: New Information Perspectives, 61(1), 5-32.

Weingart, Peter, Muhl, Claudia, \& Pansegrau, Petra. (2003). Of power maniacs and unethical geniuses: science and scientists in fiction film. Public Understanding of Science, 12(3), 279-287.

Wellington, Jerry J, \& Osborne, Jonathan. (2001). Language and literacy in science education. Buckingham: Open University Press. 
Wickman, Per-Olof, Liberg, Caroline, \& Östman, Leif. (2012). Transcending Science. In D. Jorde \& J. Dillon (Eds.), Science Education Research and Practice in Europe (pp. 39-61). Rotterdam: Springer.

Willinsky, John. (2006). The access principle: The case for open access to research and scholarship. Cambridge, Mass.: MiT Press.

Yore, Larry D, Hand, Brian M, \& Prain, Vaughan. (2002). Scientists as writers. Science Education, 86(5), 672-692.

Zimmerman, Corinne, Bisanz, Gay L., Bisanz, Jeffrey, Klein, Juliette S., \& Klein, Peter. (2001). Science at the supermarket: A comparison of what appears in the popular press, experts' advice to readers, and what students want to know. Public Understanding of Science, 10(1), 37-58.

Ødegaard, Marianne, Haug, Berit S., Mork, Sonja M, \& Sørvik, Gard Ove. (2014). Challenges and Support When Teaching Science Through an Integrated Inquiry and Literacy Approach. International Journal of Science Education, 36(18), 2997-3020. 